Nederlandse Letterkunde

http://letterkunde.letterentijdschrift.nl

Uitgave: Amsterdam University Press

\title{
Van het pad af
}

De verbeelding van lesbische liefde in proza van Edith Werkendam en Johan de Meester

Aukje van Hout

NEDLET 22 (2): 79-106

DOI: 10.5117/NEDLET2017.2.HOUT

\begin{abstract}
Strayed from the path. The portrayal of lesbian love in Edith Werkendam's and Johan de Meester's prose

Walmende lampen (1921) by Johan de Meester (1860-1931) is one of the first few literary novels that has descriptions of lesbian love. Although the novel addresses several sensitive matters, it was received relatively positive. The appreciation for the depiction of sexually deviant behaviour or perversions in literature was not self-evident: works of contemporary writer Edith Werkendam (1896-1952) received no such acclaim. That difference in reception raises a few questions, to which this article will try to find answers. Aided by the discourse analysis by Dominique Maingueneau both writers' choice of scenography for the description of their topic, which normative position they take in choosing so and how this suits the contemporary societal discourse regarding homosexuality, will be analysed.
\end{abstract}

Keywords: discourse analysis, normative analysis, realism, representation of homosexuality

Een auteur 'zal nog maar een "padvinder" zijn, maar... hem kunnen de breede scharen volgen', schrijft Jeanne Veen in 1921 in Den Gulden Winckel naar aanleiding van Walmende lampen, een roman van Johan de Meester. ${ }^{1}$ De Meester (1860-1931) was in zijn tijd een belangrijke literaire figuur: hij schreef tientallen romans, was redacteur bij De Gids en was daarnaast jarenlang verbonden aan de Nieuwe Rotterdamsche Courant, waar hij van 1891 tot 1927 redacteur van de rubriek 'Kunst en Letteren' was.

Walmende lampen is een van de weinige vroege Nederlandse literaire 
romans waarin lesbische liefde aan de orde komt, zij het dan nog zeer verhuld. ${ }^{2}$ De roman snijdt verschillende gevoelige kwesties aan, ongehuwd moederschap bijvoorbeeld, maar werd relatief positief ontvangen, voor een deel juist omdát er over dergelijke onderwerpen geschreven werd. Die waardering voor de verbeelding van perversies in de literatuur was niet vanzelfsprekend: het werk van tijdgenoot Edith Werkendam (1896-1952) was een ander lot beschoren. In 1922 verschijnt haar verhalenbundel Het purperen levenslied, een boek dat in de kritiek op flinke weerstand stuitte. In de bundel is een tweetal verhalen opgenomen over lesbische liefde. Ook in haar romans schrijft Werkendam vrijmoedig over allerlei seksuele taboes. Over het schrijftalent van Werkendam verschilden de critici van mening, maar de 'perverse' thematiek van haar werk werd vrijwel unaniem afgekeurd. ${ }^{3}$ Kennelijk was Werkendam een padvinder die te ver van het gebaande pad afweek.

De uiteenlopende receptie van het werk van De Meester en van Werkendam is opvallend. Het verschil in waardering kan worden toegeschreven aan een seksegeoriënteerde kritiek, maar ook aan de wijze waarop in de romans homoseksualiteit wordt verbeeld. Dit laatste wil ik met behulp van de discoursanalyse van Maingueneau onderzoeken. Hoe wordt over homoseksualiteit geschreven in Walmende lampen en in de boeken van Werkendam, dus welke enscenering krijgt het onderwerp? Het is daarbij zeer relevant welk normatief standpunt in het proza van beide auteurs wordt ingenomen: hoe wordt homoseksualiteit beoordeeld? Kortom: welke narratieve context gaven beide schrijvers aan hun verbeelding van homoseksualiteit? Mijn bevindingen zal ik kort toetsen aan de contemporaine receptie van de romans. Verder is het interessant om te bekijken in hoeverre die narratieve context aansluit bij het contemporaine maatschappelijke discours rondom homoseksualiteit.

\section{Literatuur als communicatie: literaire discoursanalyse}

Om deze vragen te beantwoorden maak ik gebruik van een tweetal sleutelbegrippen uit de literaire discoursanalyse van de Franse linguïst Dominique Maingueneau: scénographie en paratopie. ${ }^{4}$ Bij Maingueneau staat contextualisering centraal en wordt literatuur als een speciale vorm van communicatie opgevat. In navolging van Pierre Bourdieu beschouwt Maingueneau een auteur als iemand die voortdurend in dialoog is met het literaire veld. Tekst en context zijn daardoor onlosmakelijk met elkaar verbonden: de context bevindt zich niet alleen buiten het werk, maar is ook in het 
werk zelf aanwezig door de keuzes die een auteur maakt om zichzelf in het literaire veld te positioneren.

De werkelijkheid in literatuur wordt altijd verbeeld via een bepaalde scénographie (scenografie), die op te vatten is als een enscenering van de werkelijkheid, waardoor een verhaal ontstaat. Een scenografie is dus een soort kader, dat bestaat uit zowel paratekstuele gegevens als uit narratologische condities (zoals focalisatie of decor). De scenografie is één met het werk zelf en vormt een scharnier tussen het autonome literaire werk en dat waaruit het is voortgekomen: het statuut van de auteur en de plaats en tijd waarin hij schrijft.

Maingueneau geeft zelf enkele voorbeelden uit de Franse literatuur van een relatie tussen een scenografie en een contemporain discours, maar hoe een vergelijking in de praktijk moet worden uitgevoerd, blijft onduidelijk. Daarom kies ik ervoor om scenografieën onderling te vergelijken: verschillen en overeenkomsten tussen literaire verbeeldingen van een discours maken het statuut van de auteur en van de wereld waarin hij schreef zichtbaar. ${ }^{5}$ Een vergelijking van scenografieën maakt het mogelijk om te bestuderen binnen welke narratieve contexten een gevoelig onderwerp zoals homoseksualiteit wel of niet besproken kan worden.

Volgens Maingueneau zit in een scenografie een normatief standpunt besloten ten aanzien van het discours dat verbeeld wordt. Om dat standpunt aan het licht te brengen maak ik gebruik van de normatieve analysemethode van Vincent Jouve. Hoewel de normatieve tekstanalyse van Ruth Amossy (Argumentation dans le discours), door een overeenkomstig gebruik van begrippen, wellicht beter past bij Maingueneaus discoursanalyse, kies ik hier voor Jouve. Zijn methode is, anders dan die van Amossy, toegesneden op de analyse van literaire teksten. ${ }^{6}$

In zijn boek Poétique des valeurs zet Jouve een methode uiteen waarmee onderzoek gedaan kan worden naar de waarden die in een literaire tekst besloten liggen (de zogenaamde points-valeurs). ${ }^{7}$ In elke tekst worden bepaalde waarden uitgedrukt door de verteller, het handelingsverloop en de personages. Het handelingsverloop (manipulation) maakt deel uit van het narratieve programma en uit dat programma spreekt normativiteit. Het handelingsverloop en de 'beloning' (sanction) die een bepaald personage al dan niet ontvangt, tonen de globale waarden van een tekst. Ook een verteller kan een globale waarde uitdrukken. Personages vertegenwoordigen lokale waarden, door wat ze zeggen, denken en doen. Wat een personage zegt en denkt, kan volgens Jouve worden onderzocht op het niveau van de semantiek (wat wordt hoe gezegd), syntaxis (hoe worden gedach- 
ten geordend) of pragmatiek (welke strategie kiest een spreker om zijn boodschap over te brengen).

Een tweede concept uit Maingueneaus discoursanalyse dat hier van belang is, is paratopie. De term is een samenstelling van para (naast) en topos (plaats) en wordt door Maingueneau gebruikt om de ambivalente positie van een (literaire, vernieuwende) auteur te duiden. Hij beschouwt een auteur als iemand die tegelijkertijd wel en niet deelneemt aan het literaire veld: hij beweegt zich in dat veld en maakt er dus deel van uit, maar zet zich er ook tegen af en conformeert zich niet volledig aan de regels die er gelden.

Niet alleen de auteur van een literair werk kan een paratopische positie hebben, ook elementen binnen een scenografie in diens literaire werk kunnen paratopisch zijn. Maingueneau onderscheidt paratopische personages (personnages paratopiques), plaatsen van handeling (espaces paratopiques) en gemeenschappen (paratopies sociales). De relatie tussen deze paratopische elementen en de gevestigde maatschappij (zowel die in de romanwerkelijkheid als die daarbuiten) kan op drie manieren worden gedefinieerd: als marginaal (marginalité), antagonistisch (antagonisme) of 'exotisch' (altérité).

Paratopieën thematiseren essentiële problemen in de fictionele werkelijkheid. Ze onderhouden een relatie met de werkelijkheid buiten het boek, maar ook met een paratopische positie waarin de auteur leeft en schrijft. Maingueneau noemt die tweevoudige relatie l'embrayage paratopique, een koppeling tussen de paratopische positie van de auteur en de paratopische elementen uit het literaire werk: 'Dans ce qu'on pourrait appeler l'embrayage paratopique on a affaire à des éléments d'ordres variés qui participent à la fois du monde représenté par l'œuvre et de la situation paratopique à travers laquelle se définit l'auteur qui construit ce monde. ${ }^{8}$

Een belangrijk voordeel van Maingueneaus discoursanalyse is dat zij de mogelijkheid biedt om de auteur opnieuw in de literaire analyse te betrekken, nadat hij als onderdeel van literatuurstudie sinds het structuralisme lange tijd uit het zicht was verdwenen. Schrijverschap werd vooral - in navolging van de Amerikaanse theoreticus Wayne C. Booth - bestudeerd als problematisch concept: dat van de implied author, een onzichtbare tekstfunctie die de normen en waarden in een tekst representeert. ${ }^{9}$ Deze implied author kan enerzijds worden opgevat als een representatie van de auteur in de tekst, maar is anderzijds afhankelijk van de lezer die hem moet construeren: een dubbelzinnigheid die het een problematisch concept maakt. ${ }^{10}$ Het structuralisme wijst het concept van de implied author dan ook af en onderscheidt een strikte scheiding tussen enerzijds de auteur 
van vlees en bloed en anderzijds de verteller, die tot het narratologische domein behoort. ${ }^{11}$

Bij Maingueneau bestaat dat onderscheid niet: hij introduceert een drievoudig auteursconcept dat bestaat uit de biografische persoon (person$n e)$, de auteur (écrivain) en de inscripteur. ${ }^{12}$ De inscripteur komt deels overeen met wat we de verteller zouden noemen, maar draagt meer verantwoordelijkheid, want hij is ook verantwoordelijk voor wat Maingueneau ethos discursif noemt. Dat ethos maakt deel uit van de scenografie. De lezer kan het ethos op basis van de tekst reconstrueren, door bijvoorbeeld de woordkeuze of verteltoon (ethos montré), maar ook op basis van zelfbeschrijvende passages (ethos dit). ${ }^{13}$ Daarnaast is er het ethos prédiscursif, het beeld van de auteur dat bij de lezer bestaat alvorens hij begint met lezen. De inscripteur is dus de drager van de scenografie, maar is daarnaast ook degene die op institutioneel niveau verantwoordelijk is voor de genregebonden leescontracten waartoe een tekst uitnodigt: 'L' « inscripteur » est en effet à la fois énonciateur d'un texte particulier et, qu'il le veuille ou non, le ministre de l'Institution littéraire qui donne sens aux contrats impliqués par les scènes génériques et s'en porte garant. ${ }^{, 14}$

Maingueneau stelt de drie dimensies van de auteur voor als één geheel: ze bestaan niet onafhankelijk van elkaar. Dat impliceert dat de paratopische koppeling die hij voorstelt, op al deze niveaus bestaat. Die drievoudige relatie is op zijn minst delicaat te noemen en is niet eenvoudig te herkennen. Het gevaar van een uitleg van literatuur waarin de herkomst van dubbelzinnigheden in de roman wordt gezocht bij de personne, de auteur van vlees en bloed, ligt op de loer. Daarom zal ik de term embrayage paratopique slechts voorzichtig gebruiken, bij wijze van gedachte-experiment, en daarbij wel het onderscheid tussen personne, écrivain en inscripteur hanteren.

Een tweede voordeel van de discoursanalyse van Maingueneau is dat zij verschillende aspecten van literatuur binnen één theoretisch kader beschouwt. Zowel de aandacht voor de auteur als het onderzoeken van de verwijzingen naar de werkelijkheid is bij Maingueneau niet langer taboe. Zijn theorie biedt de mogelijkheid om zowel het werk zelf (vanuit structuralistisch oogpunt) als de schrijver en de buitenliteraire werkelijkheid in samenhang te bestuderen. 


\section{Het contemporaine discours rondom homoseksualiteit}

De scenografie is dus de literaire verbeelding van de werkelijkheid, zoals die wordt geïnterpreteerd door de auteur. Om te kunnen onderzoeken welke sporen van de werkelijkheid aanwezig zijn in de verhalen van De Meester en Werkendam, is het zinvol om het contemporaine discours rondom homoseksualiteit nader te bekijken.

Door de opkomst van de medische wetenschap en de psychiatrie ontstonden eind negentiende eeuw nieuwe benaderingen van seksualiteiten. Nieuwe manieren om het lichaam te onderzoeken vergrootten de medische aandacht voor onder andere hermafrodieten. ${ }^{15}$ Gert Hekma beschouwt de homoseksueel in zijn boek Homoseksualiteit, een medische reputatie (1987) als een sociaalhistorische 'constructie': hoewel homoseksuele handelingen al zo oud zijn als de mensheid, bestaat 'de homoseksueel' pas sinds de negentiende eeuw. In die periode wordt de homoseksueel 'uitgedokterd' en ontstaat een steeds meer medische benadering van homoseksualiteit. ${ }^{16}$

Een van de belangrijkste artsen die zich daarvoor inzette, was de Duitse seksuoloog Magnus Hirschfeld, oprichter van 's werelds eerste homorechtenorganisatie, het Wissenschaftlich-humanitäres Komitee (1897). In Nederland werden zijn denkbeelden verspreid door Jhr. J.A. Schorer, een van de eerste voorvechters van homo-emancipatie aan het begin van de twintigste eeuw. Artsen als Hirschfeld staan aan het begin van een van de belangrijkste vernieuwingen in het debat over homoseksualiteit rond de eeuwwisseling, waarbij sprake is van een overgang van ontkenning naar uitdoktering. Hirschfeld onderscheidt in zijn theorie een zogenaamde derde sekse: een mannenlichaam met een vrouwenziel of andersom. ${ }^{17}$ Daarin bestonden vele tussenvormen van mannen en vrouwen: de zogenaamde Zwischenstufen. Hirschfeld verklaarde homoseksualiteit als een gevolg van het bestaan van deze Zwischenstufen, die zich niet alleen lichamelijk openbaarden, maar ook in de aanwezigheid van mannelijke of vrouwelijke eigenschappen en de daarbij horende verlangens en het object van deze verlangens. Men ging ervan uit dat die complementair waren: een 'vrouwelijke' man verlangde dus per definitie naar een echte 'mannelijke' man en een 'mannelijke' vrouw naar een 'vrouwelijke' vrouw.

Het belang van de theorieën van Hirschfeld is enorm: hij was één van de eerste artsen die homoseksualiteit als aangeboren beschouwde. Die theorie werd echter niet door iedereen gesteund. Veel wetenschappers geloofden in 'besmettelijkheid': iemand zou homoseksueel worden door een homoseksuele ervaring. In 1910 werd zelfs een wetswijziging voorgesteld waar- 
mee homoseksuele verleiding van jeugdigen strafbaar werd gesteld. Volgens dit artikel 284bis was heteroseksuele verleiding daarentegen niét strafbaar. De wet werd in 1911 aangenomen en pas in 1971 afgeschaft. ${ }^{18}$

Hirschfeld koppelde homoseksualiteit los van de reeks pathologische afwijkingen waartoe zij lange tijd behoorde. Tegenover de stereotiepe man stond het type van de 'verwijfde' homoseksueel, die gedurende de negentiende eeuw in toenemende mate voorwerp werd van een gemedicaliseerd discours dat hem als 'ziek' bestempelde. ${ }^{19}$ Andersom gebeurde hetzelfde bij 'mannelijke vrouwen': mannelijkheid van vrouwen werd ook als ziekte beschouwd en werd gezien als een signaal voor een homoseksuele voorkeur. ${ }^{20}$ Dankzij Hirschfeld ontstond er een opvatting waarin homoseksualiteit als niet-ziekelijk en ook niet uitsluitend mannelijk werd beschouwd. ${ }^{21}$ Hierdoor werd homoseksualiteit uiteindelijk niet langer veroordeeld als moreel laakbaar gedrag, maar opgevat als iets waarvoor begrip moest worden opgebracht. ${ }^{22}$

\section{$3 \quad$ Het purperen levenslied: Werkendam}

$\mathrm{Nu}$ terug naar de boeken waar het om gaat. In het jaar dat Walmende lampen verschijnt, debuteert Werkendam in De Gids, waarvan Johan de Meester op dat moment redacteur was. Ze publiceert er het verhaal 'Het beeld', waarin een monnik gevoelens krijgt voor een marmeren vrouwenbeeld. Wanneer hij zich na weken van aanbidding op afstand eindelijk aan haar durft te vergrijpen, wordt hij verpletterd door het beeld. ${ }^{23}$ Een jaar na haar debuut verscheen de verhalenbundel Het purperen levenslied (1922), met daarin opgenomen het verhaal 'Het beeld'. In deze bundel schrijft Werkendam openlijk over allerlei seksuele taboes, waaronder lesbische liefde.

Het purperen levenslied is voorzien van een motto afkomstig uit $\mathrm{La}$ souris japonaise (1921) van de Franse decadente schrijfster Rachilde (18601953): 'Où prenez vous que L'ANORMAL PUR ne vaut pas le normal IMPUR, que l'absolu dans la sincérité n'est pas préférable aux hypocrisies qui ne démontrent que l'impossibilité d'arriver à la vertu par les chemins ordinaires?'24 Het motto maakt deel uit van de paratekst en behoort tot de scenografie. Het kader waarbinnen de lezer dit boek van Werkendam moet beschouwen, is dankzij het motto direct duidelijk. Het werk van de androgyne 'homme de lettres' Rachilde was berucht en werd als pulp beschouwd, niet in de laatste plaats omdat er werd getornd aan de grenzen van seksu- 
aliteit en seksuele identiteit. ${ }^{25}$ Het zal niet verrassend zijn dat zij voor Werkendam een belangrijke inspiratiebron is geweest. ${ }^{26}$

Het motto is op te vatten als een positionering van de auteur (écrivain): Werkendam treedt hiermee in de voetsporen van Rachilde. Er wordt nergens een rechtvaardiging voor gegeven, maar het is niet moeilijk om het boek te lezen als een verwerking van Werkendams eigen levenservaringen en het boek dus te koppelen aan de personne. Het is mogelijk dat de lezer een verband legt tussen het auteursbeeld dat hij bezit vóór hij begint met lezen (ethos prédiscursif) en het boek. Dat auteursbeeld zal niet al te positief zijn geweest: al bij haar debuut had Werkendam een slechte reputatie, die werd versterkt door 'schandaaltjes' en de 'perverse' thematiek in haar literaire werk. ${ }^{27}$ Het is dus aannemelijk dat lezer het werk van Werkendam op basis van het ethos prédiscursif interpreteert als (deels) autobiografisch.

Die veronderstelling wordt ondersteund door een ander paratekstueel gegeven: de titel Het purperen levenslied. Een 'levenslied' suggereert immers dat het hier gaat om (tragische) gebeurtenissen die uit het leven gegrepen zijn. De kleur purper verwijst volgens de schrijfster naar zinnelijkheid. ${ }^{28} \mathrm{De}$ vertelwijze (o.a. de focalisatie van de personages die worstelen met hun seksuele identiteit) kan worden gerelateerd aan de inscripteur en die is verantwoordelijk voor een ander onderdeel van de scenografie: het ethos montré. Zou dit wellicht een voorbeeld kunnen zijn van een drievoudige embrayage paratopique, zoals Maingueneau die voorstelt? Paratopieën in de verhalen kunnen in dit geval in verband gebracht worden met de paratopische positie van zowel de personne, de écrivain als de inscripteur.

Het eerste verhaal uit de bundel, 'Wat niet kon', verhaalt van de liefde van kunstenares Hans voor de jonge en mooie Maddy, die zij leert kennen op de kunstacademie. Hans is een wat mannelijke vrouw met een 'robuste natuur' en 'forsche armen': een tweeslachtigheid die ook in haar naam tot uitdrukking komt. Hans denkt Maddy niet lichamelijk te begeren, maar kan het niet verdragen dat Maddy zich na een tijd verlooft met Evert. Hierdoor wordt zij zich voor het eerst bewust van haar natuur: 'Haar natuur? Was zij werkelijk anders dan anderen? Was in 't leven van een vrouw de liefde alleen veroorloofd tot den man zooals ook andersom? ${ }^{29}$ Hans durft zich voorzichtig af te vragen of er een andere vorm van liefde bestaat dan de liefde tussen man en vrouw. Na de verloving is ze is ziek van ellende en walgt van het idee van de huwelijksnacht, waarin Evert Maddy 'zal bezitten': 
Onontkoombaar stond de verschrikkelijke werkelijkheid daar en zij had het hoofd ergens willen verbergen om niet te denken, niet te denken aan dat ééne oogenblik, dat haar meer dan ooit te voren deed voelen, ontzettend en troosteloos, dat haar gevoel wel degelijk de ellendige, tegennatuurlijke neiging toonde, die zij verafschuwde. ${ }^{30}$

Het denken aan de naderende huwelijksnacht doet Hans haar 'tegennatuurlijke neiging' voelen. Uit de woordkeus van Hans (eigenlijk die van de verteller), die Jouve op het semantische niveau van zijn normatieve analyse plaatst, spreekt een negatief oordeel en dat oordeel toont de lokale waarde van het personage Hans: zij veroordeelt haar homoseksualiteit. Het woord 'ellendig' versterkt haar afschuw. Tegelijkertijd wordt er sympathie voor Hans gevraagd. Dat gebeurt door de scenografie, die zich toont in o.a. de interne focalisatie van Hans. De bemiddeling van een verteller valt hierdoor weg en daarmee ook de afstand tussen personage en lezer. De lezer leeft intensief met Hans mee en is getuige van de worsteling van Hans, die schrikt van de openbaring van haar lesbische gevoelen en diepbedroefd is, omdat zij er, ondanks haar afschuw, niets tegen kan doen.

Evert blijkt niet zo'n sympathieke vent. Hij flirt veelvuldig met vriendinnen van Maddy en heeft weinig positiefs over zijn vrouw te zeggen: volgens Evert heeft zij 'poppenhersentjes en een dito zieltje'. Toch komen hij en Hans geleidelijk nader tot elkaar. Op een zeker moment probeert Evert Hans te verleiden. Daarin ziet Hans een kans om haar liefde voor Maddy te sublimeren en zij geeft zich uiteindelijk aan Evert. De aantrekkelijkheid van Evert lijkt voor Hans vooral te zitten in het feit dat hij de man is met wie Maddy naar bed gaat. Als ze weet hoe het is om een man lief te hebben, wordt haar begeerte om Maddy 'als een man' te beminnen alleen maar sterker, ze 'geneest' dus niet van haar liefde voor haar:

Neen, het had haar gevoel voor Mad niets veranderd [...] behalve dat nu haar zinnen, na hun natuurlijke bevrediging, heviger dat besef verdrongen.... omdat het andere even goed en even krachtig een plaats behoefde, en zij kon het niet bannen, zij was immers blij het weer in zich te voelen, het sterke deel van haar wezen, haar eigen zwakte ten steun te geven....

[...] „Je bènt zoo”, zeide ze. „Waarom speel je schuilhoekje met jezelf? Je bent van Maddy vervuld tot in 't diepst van je wezen, haar bestaan is aan 't jouwe vastgegroeid als na een lang huwelijksleven. Je begeert haar heftig en altijd, je begeert haar meer en zondiger nu je weet wàt hartstocht is en als je haar in je armen had zooals Evert jou.... je zou niet meer dan man zijn, een hevige verlàngende man.... ja, zoo is het.... verberg het jezelf niet, dùrf het aanvaarden... ${ }^{31}$ 
De scenografie is hier grotendeels hetzelfde als in het vorige fragment: ook hier is Hans focalisator. Het verschil zit in de normativiteit. De gevoelens die Hans voor Maddy heeft, zijn nog steeds prominent aanwezig, ondanks dat zij haar 'natuurlijke' bevrediging bij Evert vindt. Zij moet nu meer haar best doen om dit besef te verdringen, omdat 'het andere' - haar homoseksualiteit - zo prominent aanwezig is: het behoeft 'even goed en even krachtig een plaats'. Opnieuw geeft Hans hier een lokale waarde prijs: de keuze voor het woord 'natuurlijk' om de bevrediging van een vrouw door een man te typeren, laat zien wat volgens haar de norm is. Toch is het oordeel van Hans over zichzelf nu anders: ze is ditmaal blij om 'het sterke deel' van zichzelf te voelen. Voor Hans is dat haar mannelijkheid: dat deel van zichzelf dat Maddy liefheeft en dat haar 'zwakke', vrouwelijke wezen ondersteunt. Dat zij hiermee afwijkt van de norm, boezemt haar nu minder afschuw in dan voorheen. Hans maakt dus een ontwikkeling door, die uiteindelijk resulteert in zelfacceptatie. Die zelfacceptatie zorgt voor grote opluchting en leidt ertoe dat Hans besluit open kaart te spelen: zij wil haar liefde voor Maddy en haar relatie met Evert bekennen, in een poging de valse driehoeksrelatie tot een eerlijke te maken. De reactie van Evert kwetst haar diep:

„Je bent gek”, zeide hij. „Neen, neen” antwoordde Hans, in een vreemde verlichtheid. „Ik heb haar lief. Zoo lief als ik jou heb. Ik heb haar gehad, in gedachten, honderden malen, naakt in mijn armen, ik heb haar gedroomd, nacht aan nacht, tegen mij aan als jij nu" - Evert rees op, dolle woede in zijn oogen. Met één sprong was hij op den grond. „Jji!”... zeide hij hijgend, luid in zijn verachting. „God, dat is verschrikkelijk! 't Laagste.... jij! En misschien zou je wel, hier in mijn huis”.... Hans lag met gesloten oogen, een strakke glimlach om haar mond. Evert vloekte. „Ontken het! Zeg dat het leugen is! Jij bent niet zóó.... dan zou je mij bedrogen hebben, al dien tijd en hier in mijn huis ben je gekomen om haar, om haar óók slecht te maken." ${ }^{32}$

Opmerkelijk is dat bij Evert het idee bestaat dat Maddy door Hans 'verleid' kan worden tot homoseksualiteit: hij is immers bang dat Hans Maddy ook 'slecht' wil maken. De reactie van Evert op de bekentenis van Hans is daarnaast hypocriet te noemen: hij bedriegt zijn vrouw en windt zich nu op over het feit dat hij zélf bedrogen zou zijn door Hans. Uit de formuleringen in bovenstaand fragment blijkt bovendien dat Evert zijn controle verliest. De verteller schetst door het gebruik van uitdrukkingen als 'dolle woede' en 'hijgend, luid' geen positief beeld van hem. Ook Evert zelf draagt bij aan dat negatieve beeld door zijn onafgewerkte zinnen. Hans blijft 
echter kalm, 'vreemd verlicht'. Evert wordt hier door de verteller gediskwalificeerd als iemand die serieus genomen moet worden. Daarmee wordt de lokale waarde dat homoseksualiteit 'slecht' is, vertegenwoordigd door Evert, ook tegengesproken: de ideeën van een personage dat niet serieus te nemen is, zullen immers niet snel door de lezer geaccepteerd worden. Toch loopt het niet goed af voor Hans: Maddy vergeeft Evert de affaire wel, maar Hans niet. Er blijft voor Hans niets anders over dan diep gekwetst het huis te verlaten.

\section{Paratopie in 'Zeven dagen'}

In Het purperen levenslied staat ook het verhaal 'Zeven dagen', waarin het idee van lesbische verleiding opnieuw een rol speelt. Joy logeert bij haar tante omdat haar man voor zijn werk zeven dagen op pad is. Al snel blijkt dat Joy een nogal frivool en sensueel meisje is, dat regelmatig spreekt met een 'geluksduiveltje', een metafoor voor haar zinnelijkheid. Binnen de scenografie van dit verhaal is een aantal vergelijkbare keuzes gemaakt: het hoofdpersonage is een jonge vrouw die focaliseert, waardoor de lezer haar van binnenuit leert kennen.

Op de zesde dag ontmoet Joy een bekoorlijk zigeunerinnetje met 'ontembare oogen', door wie zij vrijwel direct geïntrigeerd is. De zigeunerin is wat Maingueneau een personage paratopique de relation d'altérité noemt: ze is onderdeel van dezelfde maatschappij als Joy, maar staat daar tegelijkertijd buiten, alleen al door haar nomadische levenswijze. ${ }^{33}$ In de scenografie wordt het 'anderszijn' extra duidelijk: niet voor niets ontmoet Joy haar in het bos, een plek van afzondering. De zigeunerin is een symbool van exotisme. Haar huidskleur en de taal die zij spreekt zijn anders, maar ook op het semantische niveau van de tekst klinkt afstand. De zigeunerin krijgt geen naam, maar heet 'het kleine figuurtje', 'een bange vogel', 'het donkere wezentje', 'beeldje van vreemde schoonheid', 'de andere'. Het is waarschijnlijk juist die paratopische positie van het zigeunerinnetje die het voor de contemporaine lezer acceptabel zal maken dat de zigeunerin in meerdere opzichten 'anders' is, ook als het gaat om seksuele geaardheid. De zigeunerin zegt over vrouwen die haar bezoeken om hun toekomst te laten voorspellen: 'Soms raden zij mijn wezen - dan keeren ze zich en bedekken vol afschuw haar gelaat, zooals de vrouwen in verre landen zich sluieren voor een man. ${ }^{34}$ De angst die deze vrouwen voor het (homoseksuele) verlangen van de zigeunerin hebben, was ongetwijfeld herkenbaar voor de contemporaine lezer. Aan die afschuw, die een lokale waarde 
is, wordt in eerste instantie getornd door Joy, die de zigeunerin bij haar thuis uitnodigt. Daar begint een sensueel spel en meent de zigeunerin dat Joy openstaat voor haar liefde:

„Straks.... las ik het in je oogen. Vergis ik me?” Joy dacht aan het begonnen spel van straks, toen aan het dierbare mannengelaat en glimlachte. "Ja," vormden haar lippen. Maar ze zag de smeekende oogen en voelde het duiveltje in haar bloed. „Neen,” zei ze langzaam. Er was een vreemde stilte in de kamer, na het frivool gegooide woord. ${ }^{35}$

Joy reageert door de gedachte aan haar man in eerste instantie afwijzend, maar corrigeert zichzelf vrijwel direct, door de influistering van wat zij haar duiveltje noemt. Na deze bekentenis ontstaat er een seksueel geladen spanning tussen de twee meisjes. Joy is overrompeld door het verlangen van de ander; een verlangen dat haar een ogenblik volledig beheerst. Het komt tot een omhelzing en er volgt een moment van intimiteit, een moment van 'menschelijk begrijpen'. Dan kust de zigeunerin Joy: 'Het zigeunermeisje, haar eigen weg volgend, omspande met beide armen Joy's lichaam, hief met een ruk het hoofd uit de het omvattende handen en zocht, met vreugde-schitterende oogen, met vochtige lippen Joy's mond. ${ }^{36}$ Het tussenzinnetje 'haar eigen weg volgend' is voor een nomadisch type opvallend dubbelzinnig. De zigeunerin volgt letterlijk en figuurlijk 'haar eigen weg' en treedt buiten de gebaande paden met haar lesbische gevoelens. Deze vrijheid heeft de nomadische zigeunerin kennelijk wél, maar de sedentaire Joy niet. Zij komt direct na de zoen dan ook tot bezinning:

Joy, in den plotsen, alles-overheerschenden walg die slechts één kracht was in haar, had zich van het meisje afgeslingerd en stond nu, met verlamde beenen in den versten hoek van het vertrek. Er was niets dan haar trillende adem en het gesmoord klagen aan de kamerdeur. En de keten, die de zielen bindt, brak. ${ }^{37}$

Hoewel de meisjes in eerste instantie nader tot elkaar lijken te komen, schrikt Joy zo van de kus die zij krijgt, dat zij het zigeunerinnetje van zich af werpt. De lezer volgt hier opnieuw Joy's gevoelens en haar worsteling daarmee: zelfs zij kent de walging die de vrijpartij bij de lezer uit 1922 kan wekken. De verteller geeft de lezer echter een andere boodschap (een globale waarde) mee: hij duidt het verbreken van de omhelzing als het breken van een keten die zielen bindt: niet als de beëindiging van iets immoreels, maar van iets innigs. 


\section{$5 \quad$ Als lot en leven dobbelen: zoektocht naar maatschappelijke acceptatie}

Werkendams eerste roman, Als lot en leven dobbelen (1923) zorgde wederom voor veel commotie. De roman gaat over de afzichtelijke 'aapachtige' kunstenares Dio, die als een kluizenaar leeft. Dio voelt zich 'een eeuwige beleediging van de wereld'. Haar enige contact met de buitenwereld verloopt via haar schrijfwerk. Om zichzelf 'bestaanbaar' te kunnen maken, wil Dio 'zoeken naar zichzelf in anderen vorm'. Daartoe gaat Dio in een bordeel op zoek naar een geschikt meisje. Haar wens om zichzelf in een andere, meer maatschappelijk geaccepteerde vorm te hervinden, lijkt een metafoor voor de worsteling van de homoseksueel. Werkendam spreekt hier over homoseksualiteit in meer versleutelde vorm dan in Het purperen levenslied. De keuze voor zo'n metafoor maakt deel uit van de scenografie en die scenografie maakt het mogelijk om over een onderwerp als homoseksualiteit te spreken.

De roman werd sterk afgekeurd. Een uitzondering op de algemene afkeuring is de bespreking van Johan de Meester in De Gids. Zijn oordeel is niet onverdeeld positief, maar hij is wat milder dan anderen als hij spreekt van een 'in beteren zin ongewonen en knap, zij het vaak wat slordig geschreven roman. ${ }^{38}$ Het relatief positieve oordeel van De Meester kan te maken hebben met de compassie waarmee hijzelf over seksuele 'afwijkingen' schreef in zijn roman Walmende lampen, waarover later meer.

Het is opvallend dat De Meester autobiografische elementen in de roman herkent en dan vooral in het personage Dio. Werkendam kenschetst haar als volgt:

Haar verschijning had al eenige beroering teweeg gebracht. Onder de ouderen werd haar naam met een schouderophalen genoemd; afgunst en toch niet te onderdrukken bewondering waren beurtelings in de onverschilligheid, waarmede zij zich trachtten te redden. De jongeren in de kunst waren trotsch op haar. - Eindelijk één die durft! riepen zij [... ${ }^{39}$

'Autobiografie?', vraagt De Meester zich af. De keuze van de écrivain Werkendam voor een beruchte schrijfster (Dio) als hoofdpersonage, is onderdeel van de scenografie en zal niet toevallig zijn. Het is niet moeilijk om hierin een autobiografisch motief van de personne te herkennen: in 1928 is Werkendam een enigszins bekende en minstens zo beruchte naam in de literaire wereld. Haar positie in het literaire veld is, net als de positie van Dio in de maatschappij, paratopisch. Werkendam maakt tegelijkertijd wel 
en geen deel uit van dat veld, doordat zij zich aan een hybridisch genre waagt, een genre dat zich ophoudt tussen literair proza en immorele pulp (pornografie, volgens sommige critici). Dio heeft een vergelijkbare paratopische positie: zij maakt door haar kluizenaarsbestaan wel en niet deel uit van de maatschappij. Door de thematiek van haar oeuvre is zij, net als Werkendam zelf, berucht in de literaire wereld. De scenografie maakt het in dit geval aannemelijk een embrayage paratopique tussen het personage Dio en de écrivain Werkendam te zien.

\section{De goddelijke zonde}

In 1928 verschijnt Werkendams laatste roman over homoseksualiteit: De goddelijke zonde. De roman beschrijft de seksuele ontwaking en zoektocht naar liefde van de jonge danseres Sylvie Herold. De titel van de roman maakt opnieuw direct duidelijk in welk licht de lezer de roman moet beschouwen: de paradoxale titel is een correctie op een visie waarin homoseksualiteit - door critici ook als dusdanig in de roman herkend - als zondig wordt beschouwd.

De roman wordt voorafgegaan door een motto afkomstig van Plato. De herkomst van het motto is niet geheel duidelijk, maar het lijkt een parafrase van de speech van Diotima (het is waarschijnlijk geen toeval dat het hoofdpersonage uit Als lot en leven dobbelen Dio heette) over Eros, afkomstig uit Plato's Symposion. Symposion is een dialoog over de oorsprong, aard en het doel van de liefde en handelt over zowel hetero- als homoseksuele liefde. Het motto is op te vatten als een verdediging van homoseksualiteit, die als de zuiverste liefde wordt gepresenteerd. De écrivain geeft door middel van dit motto te kennen dat het relaas van Sylvie gelezen moet worden als een zoektocht naar zuivere liefde, een ware verbintenis.

Sylvie beweegt zich in een kunstenaarsmilieu: zij is danseres. Het kunstenaarsmilieu dat beschreven wordt is onderdeel van de scenografie en is een voorbeeld van wat Maingueneau een paratopie sociale noemt: een gemeenschap die onderdeel is van een maatschappij, maar daar tegelijkertijd buiten valt, in dit geval vanwege een andere, 'vrijere' moraal. De keuze van de écrivain om zijn hoofdpersonage in een dergelijk milieu te plaatsen, is een strategie om dat personage buiten de eisen van het dagelijks leven en zijn conventies te plaatsen. Hierdoor wordt een lesbische liefde denkbaar.

Dansen is een wezenlijk onderdeel van de roman: het staat symbool voor de emoties en verlangens van Sylvie, voor haar onafhankelijkheid. Dansen (vaak naakt) brengt haar - en haar publiek - in extase en zij kan 
zich hierdoor geheel overgeven aan haar (erotische) gevoelens. Niet voor niets loopt Sylvie's eerste relatie stuk, omdat haar man haar verbiedt te dansen - zij wordt gedwongen haar vrijheid op te geven. Sylvie heeft op jonge leeftijd twee relaties met mannen, die haar beiden hopeloos teleurstelden. Wanneer zich dan een nieuwe man aandient, denkt zij: 'Wat brachten ze haar? [...] Moest er dan altijd een man zijn? ${ }^{40}$

Sylvie verhuist naar Parijs, wat geen toeval is: wat in Nederland niet mogelijk is, namelijk de liefde voor vrouwen, wordt in Nederlandse romans vaak in het buitenland vormgegeven. ${ }^{41}$ In Parijs ontmoet Sylvie na één van haar optredens de ruim tien jaar oudere Agnes d'Aubry, voor wie zij warme gevoelens ontwikkelt. Het is Agnes die haar het alternatief voor een man suggereert, wanneer zij vertelt over haar eigen mislukte huwelijk. In Sylvie herkent Agnes een vriendin, een zielsverwant: net als zijzelf is Sylvie een onafhankelijke vrouw die op gelijke wijze liefheeft en enkel naar haar hart luistert. Agnes - oudere vrouw met veel levenservaring - wijst Sylvie op de mogelijkheid van lesbische liefde, iets waarover Sylvie naar eigen zeggen nog nooit heeft gedacht, maar die mogelijkheid komt haar uiteindelijk niet meer dan logisch voor. Door mannen teleurgesteld en gekwetst, kan zij bijna niet anders dan vluchten in de armen van een vrouw. Er ontstaat een vriendschappelijke liefde, zonder 'hartstochtdaad', hoewel Sylvie erotische fantasieën over Agnes heeft. Agnes ziet de liefde echter als platonisch ideaal.

Net als Hans in 'Wat niet kon', heeft Agnes mannelijke eigenschappen. Sylvie ziet in haar een soort vereniging van man en vrouw: 'haar intelligentie ging verder dan die van een man en had er alle forschheid, alle logica van, zonder dat het haar in het minst ook maar tegenstond. ${ }^{42}$ Ook in haar uiterlijk vertoont Agnes mannelijke trekken: zo heeft ze brede schouders en is 'groot' gebouwd. Dankzij Agnes ontwikkelt Sylvie zich 'naar dien kant, die haar tot nu toe onbekend gebleven was'. Nog voor de liefde tussen Sylvie en Agnes zich verder kan ontwikkelen, slaat het noodlot toe: Agnes verongelukt, Sylvie is ontroostbaar. Wanhopig en verdrietig vraagt zij zich af of zij ooit een zielsverwante geliefde vinden zal: 'Waar was haar tweede helft, haar dubbele Ik? Was die man, was die vrouw? Wat kon het haar schelen, als ze het maar vond! ${ }^{43}$

Dat Sylvie zich uiteindelijk tot vrouwen wendt, is gezien de gebeurtenissen misschien niet verrassend. De inscripteur rechtvaardigt dit: hij fulmineert in de roman op verschillende momenten flink tegen mannen, die hij inferieur acht aan vrouwen vanwege hun primitieve instinct: 
... Zij [Agnes en Sylvie] spraken er dikwijls over, over den man. Zij zagen hem objectief, beschouwden hem als een voorwerp, daar gezet om ontleed te worden als een curieus feit. [...] Zij zagen zijn goede en kwade eigenschappen, gaven hem volkomen de plaats die hem maatschappelijk toekwam en hadden geen bitse woorden op zijn ontrouw, zijn kortzichtigheid, zijn brute kracht die hem instinctief is en hem zoo dicht bij het oer-dier bracht, alsof de eeuwen van beschaving en ontwikkeling geen invloed gehad hadden op de leiddraad van zijn geslachtsorganisme. ${ }^{44}$

De inscripteur gaat hier in het beschrijven van zijn afkeer van de man verder dan de personages, die in hun beschouwingen 'objectief blijven en aandacht hebben voor zowel zijn goede als slechte kanten. De inscripteur etaleert zijn afkeer door middel van een stijlfiguur, wat behoort tot zijn ethos montré. Hij geeft niet enkel weer waarover de twee vrouwen wél spreken, maar benoemt ook hetgeen waarover zij niét spreken, maar wat volgens hem wel gerechtvaardigd zou zijn. Daarmee geeft hij uitdrukking aan een globale waarde, die zich bevindt op wat Jouve het pragmatische niveau van de tekst noemt.

Een nieuwe liefde presenteert zich uiteindelijk aan Sylvie in de persoon van Dorine de Rassart. Er is direct sprake van een zekere erotische spanning tussen beiden - Dorine maakt bij Sylvie 'alles wat nog slapend was' los. Voor het eerst geeft Sylvie toe aan haar gevoelens voor een vrouw en wanneer haar verlangen door Dorine beantwoord wordt en zij samen in bed belanden, denkt ze:

Wat ik doe is liefde. Niet hartstocht uit aangeboren dualisme, noch uit slapende ondeugd, noch als uiting van de sterkere, die in ieder menschelijk wezen is. Uit behoefte aan troost. Omdat wij, moegeloopen op ons levenspad troost behoeven als een genezing-brengenden drank. ${ }^{45}$

Voor Sylvie is de liefde voor Dorine 'echte' liefde, want zij is ingegeven door een behoefte aan troost. Het is liefde die niet voortkomt uit dualisme, dat maakt dat mannen en vrouwen (fysiek) tot elkaar worden aangetrokken. Ook is er geen sprake van opzettelijk verkeerd-doen of een uiting van aangeboren mannelijkheid (zoals bij Hans en waarschijnlijk Agnes het geval is). De relatie tussen Sylvie en Dorine is echter wederom geen lang leven beschoren: Dorine bedriegt Sylvie uiteindelijk en gaat er met al haar geld vandoor. 


\section{$7 \quad$ Walmende lampen: Johan de Meester}

Walmende lampen (1921) vertelt het verhaal van Meta, een jong meisje dat zich heeft laten bezwangeren door een getrouwde kunstenaar. Door haar vader wordt Meta met haar zoontje Baasje naar de 'veilige' anonieme wereld van Den Haag gestuurd, waar zij door zijn bemiddeling kennismaakt met Bert Hamster, hoofdredacteur van het Haagsch Nieuwsblad. Hij brengt haar in contact met een kring van kunstenaars en journalisten, stuk voor stuk 'walmende lampen': figuren die zich schuldig maken aan een vorm van onzedelijkheid. Net als in De goddelijke zonde kiest de écrivain ervoor om zijn personage in een paratopie sociale te plaatsen: een gemeenschap die een marginale relatie onderhoudt met de maatschappij, omdat zij er tegelijkertijd wel en niet deel van uitmaakt. Zij conformeert zich immers niet aan de heersende normen en waarden. Juist die ambivalente positie maakt een vrije moraal mogelijk. Aan het feit dat Meta ongehuwd moeder is, wordt dan ook weinig aanstoot genomen.

Op een bepaald moment vertelt De Wilde, een vriend van Meta, dat Isa zijn echtgenote Minnie heeft bedorven door 'erge dingen' met haar te doen. Meta begrijpt in eerste instantie niet wat hij bedoelt, maar dat verandert wanneer ze uit een stapel tijdschriften een aflevering van Courrier Français tevoorschijn trekt en daarin een prent van Forain ziet:

Twee jonge-meisjes, fragiel en met de punt-neusjes die Forain tot gewoonte werden. Ze staan, in het salon waar een avondpartij is, afgezonderd bij de vleugel. De jongste, l'ingénue, ziet bedremmeld vóór zich. De oudere, donkere, kijkt op die oogen, haar sterke blik is over het meisje...

- Et puis, zegt ze, c'est si laid un homme.

Deze zonde, die mogelijkheid...

Alsof de platen hadden misdaan, schoof Meta, opgestaan, alles bijeen, duwde, wriemelde ongeduldig, tot het zich in een stapel voegde. [... ]'t Was onzin, in zulke afschuwelijkheid iets typisch Fransch' te willen zien. Forain gaf het niet uit sympathie weer... [...] Kòn het dit van Isa zijn, de "erger dingen" met Minnie "gedaan", waar De Wilde raadselachtig van sprak? Meta voelde als schreien in zich het wenschen dat het niet zoo zou zijn, doch fel venijnig daaroverheen, een toornend aanvaarden als overtuiging. ${ }^{46}$

Het beletselteken achter 'deze zonde, die mogelijkheid...' is interessant, net zoals de 'erge dingen' waarover De Wilde spreekt. Het zijn voorbeelden van verwijzingen naar een taboe, naar datgene wat niet gezegd mag wor- 
den. Daarmee zijn dergelijke vage aanduidingen van iets veel groters het enige talige discursieve spoor van zo'n taboe. ${ }^{47}$

Meta begrijpt pas waarop De Wilde zinspeelde als ze een prent in een tijdschrift ziet: ze herkent de werkelijkheid in de kunst. Meta's conclusie dat Forain zijn onderwerp niet uit sympathie heeft weergegeven, lijkt door de scenografie in eerste instantie ook te gelden voor Johan de Meester: Meta, hoofdpersonage, focalisator en object van lezerssympathie, verafschuwt en veroordeelt het lesbische gedrag van Isa. Isa wordt bovendien door haar manier van doen en brutale uitspraken, door de verteller én door andere personages getypeerd als onvriendelijk en is daarmee een personage dat de lezerssympathie niet verdient. Het is deze scenografie, waaruit dus in eerste instantie geen positief oordeel spreekt, die het mogelijk maakt om in 1921 over lesbische liefde te spreken.

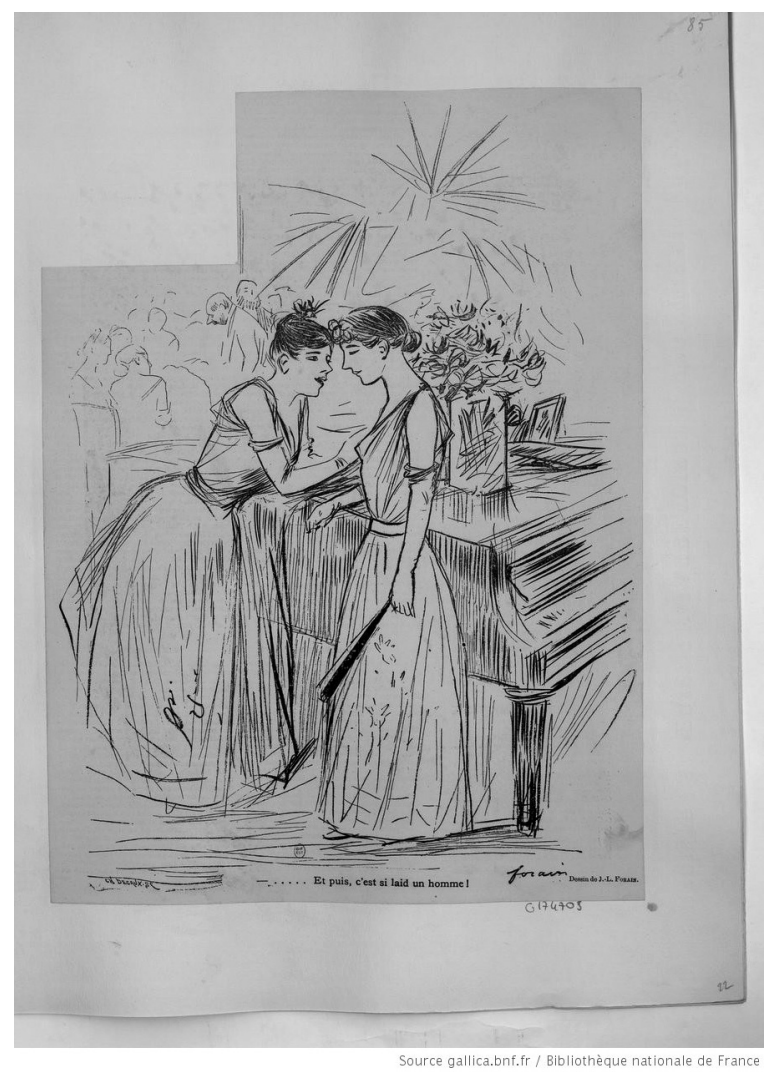

De in Walmende lampen bedoelde prent van de Franse tekenaar Jean-Louis Forain (1852-1931)

Afkomstig uit: Collection Jaquet. Dessinateurs et humoristes français des XIXe et XXe siècles (z.j.) 
Toch is er op andere plekken in de roman sprake van een correctie op dat negatieve oordeel. Dat gebeurt onder andere in de vorm van een brief van Isa aan De Wilde, waarin zij haar gedrag probeert te verklaren als een wanhopige zoektocht naar liefde en naar geluk. Ze schrijtt:

Die tijd is, ook in m'n herinnering, nog heel verward voor me. Ik wou het zoo, ik haatte mijn andere zelf, ik wou alleen maar, woest, het leven te lijf, het leven, dat me te kort deed, dat ergens groot en prachtig zijn moest, dat moest kùnnen dronken maken van weelde en mij liet hongeren, me buitensloot. ${ }^{48}$

Met deze brief vraagt Isa niet alleen begrip van De Wilde, maar eigenlijk wordt datzelfde ook van de lezer gevraagd. Het negatieve beeld van Isa als manipulatieve en kille vrouw wordt genuanceerd: zij blijkt iemand die worstelt met haar lesbische gevoelens (haar 'andere zelf) en die zich tekort gedaan voelt door het leven. Ze lijkt daarin op de vrouwen in Werkendams proza: wie heeft geworsteld met wat maatschappelijk onaanvaardbaar is, kan veel worden vergeven.

Isa is niet de enige 'walmende lamp', ook met haar broer Bert Hamster is het een en ander mis. Hamster is iemand die in aanleg twee geslachten heeft ontwikkeld, maar geen van beide is volgroeid. ${ }^{49}$ Hij verfoeit zichzelf hierom:

Wat zijn jeugd al neergedrukt had: het scheeve, het half- of tweeslachtige van zijn bestaan, hij onderging het plotseling weer $[\ldots]$. Weer drukte beschamend het karakteristieke hierin dat hij, die, in alles hybridisch, bewust zich liefhad en tevens zich haatte, bewust zich haatte als een bastert, beland was in dat bastertvak, dat bastertleven, de journalistiek. Hoofdredacteur - van een halfwaskrant. Alles aan en om hem, halfwas - nu, zooals zijn leven lang. Zijn leven lang had hij 't geweten, zijn leven lang erom gewrokt, en alle spijt bezorgd verborgen, gelijk de gierigaard een schat. 't Was het geheim van zijn geboorte, het wreede zijner lichaams-gesteldheid. ${ }^{50}$

Hamster noemt zichzelf 'in alles hybridisch', want zijn tweeslachtigheid uit zich niet alleen fysiek, maar ook in zijn gedrag: hij is wispelturig, kan geen keuzes maken en is zachtmoedig, ijdel, kortom: hij is geen 'echte' man. Het is opvallend dat zowel Isa's homoseksualiteit als Hamsters fysieke onvolmaaktheid in de roman in dezelfde categorie van seksuele 'afwijkingen' wordt geplaatst. Dat gebeurt expliciet aan het einde van de roman, wanneer De Wilde Meta tot een ander inzicht over Isa en haar broer brengt: 
Mislukkelingen, uitwassen van de natuur, afdeeling sexueele ellende. Zie zóó 't perverze van de zuster en de... halfheid in hem, die ook is in zijn geest, wellicht gevolg van fyziek gebrek. Geef ze meelij; vonnis niet! [...] U bent boos om zijn zwakke liefde, uiting van een laf karakter; beklaag hem: u voelt het zóóveel sterker; alle voorrecht is dus bij u. ${ }^{51}$

De Wilde corrigeert hier Meta's oordeel en vraagt om begrip voor Hamster en zijn zus: heb meelij en vonnis niet. Indirect wordt hiermee ook begrip van de lezer gevraagd. De Wilde's zienswijze wordt op een betekenisvolle plek aan het einde in de roman gepresenteerd en wordt door Meta hoog gewaardeerd: 'Ook zou, zoo iemand, De Wilde weten, of haar inzicht juist geweest was.' Uiteindelijk weet De Wilde Meta milder te stemmen: 'Die [fysieke en geestelijke gezondheid] is uw kostelijkste bezit, Baasje is er trouwens een brok van. En die missen hij en Isa. - Summa summarum... - Zij zijn te beklagen. ${ }^{52}$ De Wilde, die net als De Meester een ontwikkeling doormaakt van pessimisme naar compassie, heeft een levensinzicht verworven dat uiteindelijk niet alleen Meta overtuigt, maar ook de lezer, die met Meta sympathiseert. Kortom: Meta vertegenwoordigt een lokale waarde in haar afwijzing van Isa's homoseksualiteit, de globale waarde wordt uitgesproken door De Wilde.

\section{De contemporaine receptie van Walmende lampen en de romans van Werkendam}

Zoals eerder gezegd was de receptie van het werk van De Meester en Werkendam verschillend. Over de romans van Werkendam werd overwegend negatief geoordeeld. Critici spraken van een 'volslagen mal' boek of 'een monstrum' dat is 'gebrouwen uit hysterische sentimentaliteit, zieke verbeelding en overspannen hersenen'. ${ }^{53}$ Walmende lampen werd daarentegen unaniem positief ontvangen en werd door een criticus zelfs 'het beste wat in onze litteratuur is geschreven' genoemd. ${ }^{54}$ Is dat verschil in receptie op basis van de bovenstaande analyse te verklaren?

Uit de normatieve analyse blijkt dat de globale waarden ten aanzien van homoseksualiteit in de romans niet erg verschillen: in alle romans wordt begrip gevraagd voor homoseksualiteit. In dat licht is de uiteenlopende waardering opmerkelijk. Een belangrijk verschil in scenografie zou dit echter kunnen verklaren: De Meester en Werkendam maken andere keuzes ten aanzien van hun hoofdpersonage. Bij Werkendam is het hoofdpersonage telkens een jonge lesbische vrouw, die voortdurend via focalisatie 
gevolgd wordt in haar worsteling en morele ontreddering. Bij De Meester is het hoofdpersonage Meta een 'helder licht' te midden van allerlei 'walmende lampen', waartoe het lesbische personage Isa behoort. Isa wordt van buitenaf beschouwd. Mogelijk verklaart dit de uiteenlopende waardering: de meeste critici vinden dat Werkendam er nergens in slaagt een overtuigend hoofdpersonage neer te zetten, terwijl De Meester dat wel lukt. 'Overtuigend' moet hier begrepen worden als 'realistisch'. Meta's primaire reactie op de lesbische Isa is voor de contemporaine lezer waarschijnlijk herkenbaar en dus 'realistisch', maar sommige critici waren ervan overtuigd dat de sentimenten van Werkendams personages in de realiteit niet voorkomen. Regelmatig wordt Werkendams schrijven afgedaan als 'valsch', 'onwaarschijnlijk', 'onmogelijk' of 'niet gevoeld'. Jan Walch schrijft in Groot Nederland dat Werkendam de gevoelens waarover zij schrijft 'niet voldoende kent om ze te beschrijven'. ${ }^{55}$

Een andere mogelijkheid is dat de uiteenlopende waardering het gevolg is van een seksegeoriënteerde kritiek. Erica van Boven heeft vastgesteld dat sinds het begin van de negentiende eeuw vrouwelijke auteurs in toenemende mate als een aparte groep werden behandeld: hun werk werd vooral beoordeeld op grond van de vraag of de inhoud overeenstemde met de veronderstelde zedelijkheid van de vrouwelijke natuur. ${ }^{56}$ Vrouwen werden geacht niet veel te weten over zaken als economie, politiek en seksualiteit en mochten daar dan ook niet (te veel) over schrijven. ${ }^{57}$

Rond 1920 ontstond echter een subgenre van 'vrouwenromans' waarin veel aandacht is voor vrijheid binnen de liefde en waarin erotiek een grote plaats heeft. Werkendam wordt door critici, samen met onder andere Alie Smeding, Agnes Maas-van der Moer en Julia Frank, tot deze groep schrijfsters gerekend. ${ }^{58}$ Haar proza werd alleen daarom al verworpen, zo blijkt uit enkele besprekingen van haar romans. De Middelburgsche Courant hekelt in het algemeen de vrijmoedigheid waarmee in romans over seksualiteit wordt gesproken, maar specificeert dit bezwaar door de toevoeging dat men daar 'nog zonderlinger tegenover [staat] wanneer zulke dingen worden geschreven door een vrouw' ${ }^{59}$ De Bredasche Courant (net als de Middelburgsche Courant overigens niet het meest gezaghebbende dagblad op het gebied van letterkundige kritiek) schrijft: 'Wij blijven nu eenmaal bezwaar maken tegen de producten van een zekere categorie van schrijfsters die er een zeker welbehagen in schijnen te vinden een verhaal te vullen met veel overbodige details van sexueele kwestie's' ${ }^{60}$ Ook De Tijd wijst op een dergelijke 'neiging' bij vrouwen als Werkendam: 
Onderwerpen, waar een man zich niet licht aan zal wagen, worden met voorliefde door onze populair-wetenschappelijk geschoolde dames aangepakt [...]. Afin, zoolang het maar gaat „over dames, voor dames” zal ik niet gauw iets slechts zeggen van al deze beminnelijk-onbelangrijke publicaties. ${ }^{61}$

De opmerking over 'populair-wetenschappelijk geschoolde dames' is nogal denigrerend en doelt waarschijnlijk op dat sommige schrijfsters, zoals Werkendam, graag belezen voor de dag kwamen. Zij toont haar belezenheid bijvoorbeeld met haar verwijzing naar Plato, maar het is ook goed mogelijk dat Werkendam publicaties las waarin de ideeën van Hirschfeld werden uitgelegd. Iets anders wat opvalt, is dat de criticus in De Tijd expliciet veronderstelt dat de romans van Werkendam enkel door vrouwen gelezen zullen worden. Ook andere critici geloofden dit en categoriseerden haar boeken daarmee als 'vrouwenromans'. Het wordt echter ook duidelijk dat Werkendam binnen de 'categorie van schrijfsters' die in hun proza seksualiteit tot thema maakten, in haar vrijmoedigheid verder gaat dan anderen. De Nieuwe Gids schrijft: 'Edith Werkendam is een vrouw met durf, - maar in sommige bladzijden van dit werk gaat zij, - zelfs voor een schrijfster! - toch wel wat ver. ${ }^{, 62}$

Het feit dat Werkendam literaire pretenties had, was strijdig met de doorgaans lagere literaire waardering van het werk van vrouwelijke auteurs. ${ }^{63}$ Werkendams proza wordt 'geforceerd', 'hoogdravend' en 'pretentieus' bevonden. Werkendam maakt volgens Het Volk de indruk 'van een wat bleke boterbloem, die zich met alle geweld voor een orchidee wil uitgeven'. ${ }^{64}$ Werkendams eenzijdige aandacht voor 'zwoelheid' achtte men tevens niet 'artistiek - literair verantwoord'. ${ }^{65}$ De Meester schrijft in Walmende lampen in bedekte termen over de 'sexueele ellende', terwijl Werkendam daarin telkens net te ver gaat en benoemt wat de verbeelding van de lezer ook kan invullen. Voorbeelden daarvan zijn de erotische fantasieen van Sylvie over Agnes en de bordeelbeschrijvingen in Als lot en leven dobbelen.

\section{$9 \quad$ Besluit}

Het blijkt dat de scenografieën in de romans van De Meester en Werkendam vooral overeenkomsten kennen. Beide auteurs becommentariëren in hun boeken hetzelfde maatschappelijke discours: de gezamenlijke presentatie door Johan de Meester van een lesbische vrouw en een hermafrodiete man en de voorstelling van de mannelijke lesbienne bij Werkendam dui- 
den op de verwerking van de medische inzichten die ontstaan aan het einde van de negentiende eeuw. De destijds gevoerde discussie over het aangeboren karakter van homoseksualiteit vindt zijn weerslag in de hier besproken romans: in het werk van beide auteurs wordt het standpunt ingenomen dat homoseksualiteit niet iets is waartegen je je kunt verzetten en wordt daarom compassie gevraagd voor homoseksuelen. Ook het idee van lesbische verleiding is terug te vinden de romans van beide auteurs.

In vroegere literaire verbeeldingen van homoseksualiteit, bijvoorbeeld in Noodlot (1891) van Couperus of Pijpelijntjes (1904) en Pathologieën (1908) van Jacob Israël de Haan, is duidelijk sprake van een andere grondgedachte. Daarin is homoseksualiteit een uitsluitend mannelijke kwestie en steeds verbonden met geweld en manipulatie. Het zou interessant zijn om dat verschil, dat parallel lijkt te lopen met de ontwikkelingen in het contemporaine discours rondom homoseksualiteit, nader te onderzoeken.

De globale waarden in de romans verschillen weinig. Alle hier aan de orde gestelde verhalen kennen een vergelijkbare afloop, dat wat Jouve sanction noemt. Geen van de lesbische personages krijgt immers een beloning in de vorm van een gelukkige lesbische liefde. De lesbische liefde wordt in geen van deze werken als 'eindstation' gepresenteerd, maar wordt voorgesteld als een (betreurenswaardige) onmogelijkheid. Uit een dergelijke afloop zou een veroordeling van lesbische liefde afgeleid kunnen worden. Het lijkt echter aannemelijker dat er sprake is van een conventionele keuze: zelfs Werkendam durfde zich kennelijk niet te wagen aan de voorstelling van een gelukkige en bevredigende seksuele relatie tussen twee vrouwen.

Een verkenning van de kritische receptie van de bestudeerde werken van De Meester en Werkendam lijkt bestaande inzichten over de verschillende normen die er in het literaire veld bestonden voor schrijvers en schrijfsters te bevestigen. De uitkomsten van de discoursanalyse maken het mogelijk deze institutionele normen te relateren aan scenografieën in de besproken boeken en het statuut van de auteur. De globale opvatting over wat een schrijfster rond 1920 was toegestaan in de verbeelding van seksualiteit kan met behulp van een discoursanalyse worden getoetst aan elke afzonderlijke roman. Hierdoor wordt in de verschillende receptie van de boeken van De Meester en Werkendam zichtbaar hoe die opvatting in praktijk werd gebracht.

Het voornaamste verschil tussen de scenografieën bestaat uit het gekozen hoofdpersonage: bij De Meester is dat een buitenstaander, iemand met wie de (contemporaine) lezer zich makkelijker identificeert dan met het hoofdpersonage van Werkendam, bij wie de lezer meeleeft met een 
lesbische vrouw. Werkendams keuze voor een lesbisch hoofdpersonage zal niet toevallig zijn. Het lijkt mogelijk om Werkendam te beschouwen als een lesbische schrijfster (écrivain) die gestalte geeft aan persoonlijke ervaringen (van de personne). Met enige terughoudendheid zou er in dit verband wellicht gesproken kunnen worden van een embrayage paratopique.

De Meester heeft een andere maatschappelijke positie dan Werkendam en heeft een andere positie in het literaire veld. Niet alleen is hij een man en kan hij zich dus meer permitteren, hij is ook een gevestigd schrijver. Dat maakt uitgerekend De Meester tot de padvinder die Jeanne Veen in Den Gulden Winckel voor ogen had: een padvinder die door de 'breede scharen' gevolgd kan worden.

\section{Noten}

1. Veen (1921).

2. Een overzicht van romans van tussen 1880-1940 waarin liefde tussen vrouwen voorkomt, is opgesteld door Myriam Everard (1983). Zie ook Mak (1988) en Meurs (1990). De methode die Everard gehanteerd heeft bij het samenstellen van deze lijst blijkt echter ontoereikend: Walmende lampen komt opvallend genoeg niet op haar lijst voor, terwijl de roman bijvoorbeeld wel op de zogenaamde Schorerlijst te vinden is. Walmende lampen heeft al een van de eerste romans de op medische inzichten geschoeide 'uitgedokterde' homoseksueel als onderwerp.

3. Schuyf (1994), 182.

4. Maingueneau (1993). De toepassing van de discoursanalyse van Maingueneau heeft tot op heden relatief weinig aandacht gekregen in de Nederlandse letterkunde. Ik heb voor dit artikel gebruik gemaakt van een drietal recentelijk verschenen publicaties waarin de discoursanalyse van Maingueneau wordt verkend: Vandevoorde \& Van Zoggel (2014), Ham (2015) en Van de Schoor (2016). Ook dank ik Mariska Thurlings voor haar hulp bij het begrip van de discoursanalyse van Maingueneau. Ik heb dankbaar gebruik gemaakt van haar teksten uit het studieboek Discoursanalyse in praktijk, dat momenteel in voorbereiding is.

5. Maingueneau (1993), 135 .

6. Amossy (2012).

7. Jouve (2001).

8. Maingueneau (1993), 174.

9. Kindt \& Müller (2006), 2.

10. Kindt \& Müller (2006), 63-68; Sergier, Vandevoorde \& Van Zoggel (2014), 7.

11. Herman \& Vervaeck (2009), 25-26.

12. Maingueneau (2004), 106-109. Ook Jérôme Meizoz maakt, in navolging van Maingueneau, gebruikt van dit auteursconcept. Zie Meizoz (2007), 24-25. Zie ook Ham (2015), 3536.

13. Maingueneau (2014). Zie ook: Sergier, Vandevoorde \& Van Zoggel (2014), 10.

14. Maingueneau (2004), 108. Zie ook Sergier, Vandevoorde \& Van Zoggel (2014), 9.

15. Mak (2008), 48-49. 
16. Hekma (1987), 49-50.

17. Van der Meer (2007), 116-123.

18. Van der Meer (2007), 136-143. Hekma (1987), 202-206.

19. De Smaele (2006), 7 .

20. Mak (1997), 352-359. Zie ook Mak (2002), 312-313.

21. Hekma (1987), 72 .

22. Kemperink (2014), 43.

23. Sander Bink maakt in Zacht Lawijd (2005) aannemelijk dat de liefde voor levenloze objecten in met name de decadente literatuur van het fin de siècle geen onbekend motief is. De Nieuwe Gids (1923) wijst in de bespreking van Het purperen levenslied op de overeenkomst met een verhaal uit de bundel Zwarte vlinders (1895) van M. Snijder van Wissenkerke, waarin eveneens een beeld door een man wordt bemind. Ook het meer recente Kort Amerikaans (1962) van Jan Wolkers kent dit motief.

24. Vrij vertaald: waaraan ontleent $u$ de gedachte dat het zuivere afwijkende niet evenveel waard zou zijn als het onzuivere alledaagse, dat absolute oprechtheid niet te verkiezen is boven de hypocrisie die alleen maar de onmogelijkheid laat zien om langs normale weg tot deugdzaamheid te komen? Rachilde (1921).

25. Wilson (2015).

26. Bink (2005), 6 o.

27. Bink (2005), 6 o.

28. Schuyf (1994), 183.

29. Werkendam (1922), 84 .

30. Werkendam (1922), 85 .

31. Werkendam (1922), 96.

32. Werkendam (1922), 99-100.

33. Zie hiervoor ook: Van de Schoor \& Sintobin (2010).

34. Werkendam (1922), 158.

35. Werkendam (1922), 159 .

36. Werkendam (1922), 161.

37. Werkendam (1922), 161.

38. De Meester (1923).

39. Werkendam (1923), 97.

40. Werkendam (1928), 141.

41. Schuyf (1994), 183.

42. Werkendam (1928), 170.

43. Werkendam (1928), 181.

44. Werkendam (1928), 173.

45. Werkendam (1928), 207.

46. De Meester (1921), 174-175. De prent bestaat en was bekend in Nederland, net als de tekenaar Jean-Louis Forain (1852-1931). Cornelis Veth heeft in zijn boekje Fransche caricaturisten (1918) een hoofdstuk gewijd aan Forain. De prent uit Walmende lampen, die niet is afgedrukt, beschrijft hij als volgt: 'Een vrouw met korte haren, starre oogen, een vrouw van de vierde sexe, fluistert tot een jong meisje als laatste argument: "Et puis, c'est si laid, un homme".' (100-101).

47. Sintobin \& De Pater (2014), 19-20. Zie ook: Mak (1988), 157.

48. De Meester (1921), 151-152.

49. In de roman zelf wordt niet expliciet benoemd wat het gebrek van Bert Hamster is, maar Johan de Meester noemt hem in De Gids (1921, I, 482) een hermafrodiet.

50. De Meester (1921), 115 . 
51. De Meester (1921), 302-303.

52. De Meester (1921), 301.

53. Scharten (1924); Groot Nederland (1923), 755.

54. Kr. (1921).

55. Groot Nederland (1923), 756.

56. Van Boven (1992), 250. Zie ook: Streng (1997), 82 en (2015), 102.

57. Idem.

58. Bel (2016), 695 en Van Boven (1992), 94.

59. Middelburgsche Courant (1923).

6o. Bredasche Courant (1929), n.a.v. de tweede druk van Als lot en leven dobbelen. Opvallend genoeg beleefde deze roman, die van alle romans van Werkendam het meest negatief werd ontvangen, wel een herdruk.

61. H.K. (1929).

62. De Nieuwe Gids (1924), 114.

63. Streng (1997), 73 en (2015), 102.

64. Het Volk (1922).

65. Walch (1923).

\section{Bibliografie}

Amossy, R., Argumentation dans le discours, Armand Colin, Parijs, 2012.

Bink, S., 'De kleine garnaal: Edith Werkendam', in: Zacht Lawijd 5, 2005, 1, 58-73.

Bel, J., Bloed en rozen. Geschiedenis van de Nederlandse literatuur 1900-1945, Bert Bakker, Amsterdam, 2015 .

Boven, E. van, Een hoofdstuk apart. "Vrouwenromans" in de literaire kritiek 1898-1930, Sara/Van Gennep, Amsterdam, 1992.

Everard, M., 'Galerij der vrouwenliefde. "Sex variant women” in de Nederlandstalige literatuur 1880-1940', in: M. Duyves, e.a. (red.), Homojaarboek 2, Van Gennep, Amsterdam, 1983, 180-212.

Everard, M., Ziel en zinnen. Over liefde en lust tussen vrouwen in de tweede helft van de achttiende eeuw, Historische Uitgeverij, Groningen, 1994.

Groot Nederland, 'Het purperen levenslied', in: Groot Nederland 21, 1923, I, 755-756.

Ham, L., Door Prometheus geboeid. De autonomie en autoriteit van de moderne Nederlandse auteur, Verloren, Hilversum, 2015.

Hekma, G., Homoseksualiteit, een medische reputatie. De uitdoktering van de homoseksueel in negentiende-eeuws Nederland, SUA, Amsterdam, 1987.

Herman, L. \& Vervaeck, B., Vertelduivels. Handboek verhaalanalyse, Vantilt, Nijmegen, 2009.

H.K., 'Men bekroont', in: De Tijd, 1 juni 1929.

Jouve, V., Poétique des valeurs, Presses Universitaires de France, Parijs, 2001.

Kemperink, M., 'Louis Couperus en Jacob Israël de Haan in het licht van het medische discours over homoseksualiteit rond 1900', in: Buul, A. van, Pater, B. de, Sintobin, T. \& Vandevoorde, H. (red.), Onnoemelijke dingen. Over taboe en verbod in het fin de siècle, Verloren, Hilversum, 2014, 39-57. (Rythmus. Jaarboek voor de studie van het fin de siècle, 3).

Kindt, T. \& Müller, H., The implied author. Concept and Controversy, Walter de Gruyter, Berlijn, 2006.

Kr., 'Walmende lampen van Johan de Meester', in: Arnhemsche Courant, 19 februari 1921.

Maingueneau, D., Le contexte de l'oeuvre littéraire. Énonciation, écrivain, société, Dunod, Parijs, 1993. 
Maingueneau, D., Le discours littéraire. Paratopie et scène d'enonciation, Armand Colin, Parijs, 2004.

Maingueneau, D., 'Le recours à l'ethos dans l'analyse du discours littéraire', in: Fabula, Les colloques, Posture d'auteurs: du Moyen Âge à la modernité. URL: http://www.fabula.org/colloques/ document2424.php

Mak, G., 'Grenzen aan het spreken over het lesbische. Seksualiteit en erotiek tussen vrouwen in Nederlandse romans (1900-1920)', in: Lover 15, 1988, 3, 156-163.

Mak, G., Mannelijke vrouwen. Over grenzen van sekse in de negentiende eeuw, Boom, Amsterdam/ Meppel, 1997.

Mak, G., 'Het vrouwelijke zelf. Identiteit, seksualiteit en casuïstiek', in: Nys, L., Smaele, H. de, Tollebeek, J. \& Wils, K. (red.), De zieke natie. Over de medicalisering van de samenleving 1860 1914, Groningen, 2002, 298-319.

Mak, G., 'Lichaamsgeschiedenis, sekse en zelf, in: Dubbe, Z. (red.), Lïf en leden. Gender en het historische lichaam, Aksant, Amsterdam, 2008, 34-60. (Jaarboek voor vrouwengeschiedenis 28).

Meer, T. van der, Jonkheer mr. Jacob Anton Schorer (1866-1957). Een biografie van homoseksualiteit, Schorer Boeken, Amsterdam, 2007.

Meester, J. de, Walmende Lampen, Van Dishoeck, Amsterdam, 1921.

Meester, J. de, 'Aantekeningen en opmerkingen', in: De Gids 85, 1921, I, 481-486.

Meester, J. de, 'Nieuwe Nederlandsche vertelling II', in: De Gids 87, 1923, IV, 449-456.

Meizoz, J., Postures littéraires. Mises en scène modernes de l'auteur, Slatkine Érudition, Genève, 2007.

Meurs, J., 'Tribadie als symptoom van ziekte en verval. Vrouwelijke homoseksualiteit in populaire Nederlandstalige literatuur rond 1900', in: Baar, M. de, e.a. (red.), In de ban van het verhaal. Jaarboek voor Vrouwengeschiedenis 11 (1990), SUN, Nijmegen, 1990, 55-78.

Middelburgsche Courant, 'Als lot en leven dobbelen', in: Middelburgsche Courant, 20 november 1923.

De Nieuwe Gids, 'Het purperen levenslied, door Edith Werkendam', in: De Nieuwe Gids 38, 1923, II, 594-595.

Rachilde, La souris japonaise. Roman, Flammarion, Parijs, 1921.

Scharten, C., 'Een monstrum', in: De Telegraaf, 3 mei 1924.

Schoor, R. van de, 'Auteursvariant, "variance" of "duplicité énontiative"? Herlezing van Carel Vosmaers Vlugmaren en Vogels van diverse pluimage', in: Nederlandse letterkunde 21, 2016, 1, $35-63$.

Schoor, R. van de \& Sintobin, T., "Er zijn wetten, die het verbieden” Topoi in de moderne Vlaamse literatuur: de uithoek', in: Mededelingen van het Cyriel Buysse Genootschap XXVI, Gent, 2010.

Schuyf, J., Een stilzwijgende samenzwering: lesbische vrouwen in Nederland, 1920-1970, Stichting Beheer IISG, Amsterdam, 1994.

Sintobin. T. \& De Pater, B., "Dingen waar men liefst niet over spreekt” Een verkenning van taboe en gebod rond 1900', in: Buul, A. van, Pater, B. de, Sintobin, T. \& Vandevoorde, H. (red.), Onnoemelijke dingen. Over taboe en verbod in het fin de siècle, Verloren, Hilversum, 2014, 9-22. (Rythmus. Jaarboek voor de studie van het fin de siècle, 3 ).

Smaele, H. de, 'Een beeld van een man. Mosse en het moderne mannelijke stereotype', in: Tijdschrift voor genderstudies 9, 2006, 3, 5-18.

Snijder van Wissenkerke, M., Zwarte vlinders, Elsevier, Amsterdam, 1895.

Streng, T., Geschapen om te scheppen? Opvattingen over vrouwen en schrijverschap in Nederland, 1815-1860. Amsterdam University Press, Amsterdam, 1997.

Streng, T., 'Gender en boekbedrijf, in: Nederlandse letterkunde 20, 2015, 2, 93-133. 
Vandevoorde, H. \& Van Zoggel, M., 'De auteur als Lazarus', in: Sergier, M., Vandevoorde, H., \& Van Zoggel, M. (red.), De auteur. CLW 6, Academia Press, Gent, 2014, 5-18.

Veen, J., in: Den gulden winckel 20, 1921, 4, 59.

Veth, C., Fransche caricaturisten, Slijthoff, Leiden, 1918.

Werkendam, E., Het purperen levenslied, Querido, Amsterdam, 1922.

Werkendam, E., Als lot en leven dobbelen, Querido, Amsterdam, 1923.

Werkendam, E., De goddelijke zonde, Querido, Amsterdam, 1928.

Wilson, S., 'The Quest for Fictionality: Prostitution and Metatextuality in Rachilde's Monsieur Vénus', in: Modern Languages Open, 2015. URL: http://doi.org/10.3828/mlo.voio.20.

\section{Over de auteur}

Aukje van Hout werkt via een promotiebeurs voor leraren van NWO bij de Radboud Universiteit Nijmegen aan haar proefschrift over Johan de Meester (1860-1931) en het realistisch proza van rond 1900. Daarnaast werkt zij als docente Nederlands aan het Dominicus College te Nijmegen.

E-mail: a.vanhout@let.ru.nl 